\title{
The State-Moro Armed Conflict in the Philippines Unresolved National Question or Question of Governance?
}

\author{
RIZAL G. BUENDIA*
}

The continuing struggle of the Moro secessionist movement in the Philippines is one of Southeast Asia's longest armed conflicts. The tenacity of the conflict lies in two competing concerns: the assertion of self-determination rights of the Moro separatist movement; and the affirmation of the Philippines' sovereign right to territorial integrity. However, beneath these rights are crucial issues that remain unanswered both by the contending forces-problems where internecine violence and conflict emanate from. This article argues that self-determination rights can be adequately exercised by people who have clearly defined their national identity and concept of a nation. Unfortunately, the Moro multi-ethnic national identity has yet to be crystallized while the idea of a Bangsamoro (Bangsa Nation) remains weak. On the other hand, the state has yet to address the Moros' legitimate demands of political autonomy, socio-economic development, and social justice and discrimination. Without underestimating the ethnic component of secessionism, the article concludes that poor governance has prolonged, complicated, and further justified the Moros' quest to secede from the Republic.

\section{Introduction}

The Mindanao conflict, expressed in Muslim armed resistance against the Philippine state, has deep historical roots and resolution is definitely not easy. The armed conflict which has been fought under two competing banners of national selfdetermination on the one hand, and protection of state rights on the other hand, has taken thousands of lives, destroyed millions worth of properties, and displaced a magnitude of people who sought refuge in other regions of the country as well as in neighboring countries. The territorial question has been disputed more often in the battlefields than over a negotiating table.

The Muslim secessionists prefer to be called Moros $^{1}$ rather than Filipinos. They believe that their people have never been part of the Philippines and their current struggle is a continuation of their ancestors' war for independence, which was

\footnotetext{
* Rizal G. Buendia, PhD, is Associate Professor at the Political Science Department, De La Salle University-Manila, Philippines.
} 
first launched against Spanish and American rule, and presently under the postcolonial "Filipino-run Philippine state." On the other side, the state contends that the separatist movement has to acknowledge the existence of a sovereign Philippine state whose territorial jurisdiction has been defined in accordance with the international law. Hence, the state views the ongoing armed struggle of the Moros as an act of secession against a legitimate state while the former declares it an exercise of the people's "right to self-determination" against a state which "illegitimately annexed" the Bangsamoro. ${ }^{2}$

This article examines two competing perspectives in nation-state building espoused by the Muslim minorities and Philippine state. It traces both the historical antecedents and consequences of Moro-state conflict, the relevant and primary actors involved in the conflict as well as their motives and strategies in realizing their objectives, and the roots of the political violence. Towards the end of the article, a general assessment of the prospects of resolving the ongoing conflict is made.

The article argues that the Moros self-determination struggle, without underestimating the ethnic content of the resistance movement, is triggered and drawn out more by the combined causes of state's centralism that restrict their self-governing power, socio-economic grievances and deprivation, and perceived injustices, discrimination, and alienation of the people from the mainstream of Philippine political and economic development rather than an overarching movement with a single concept of a Bangsa Moro (Moro Nation). A Bangsa Moro consciousness and national unification among Philippine Muslims has yet to be achieved. The article concludes that the armed conflict between the Moros and the state is more of a contestation of democratic space where expansive and interactive governance can 
function and thrive both for the minorities and majorities rather than a question of Moro national self-determination.

\section{Ethnogenesis of Moro and the Colonial State}

The term Moro was the appellation applied by the Portuguese, who seized Melaka in 1511, to all Muslim population of Southeast Asia. ${ }^{3}$ It was the name used by the Spaniards to refer to Muslim inhabitants in the Philippines alluding to the Muslim Moorish occupation of the Iberian Peninsula and the northern coast of the African continent in 711 A.D. When the Spaniards crossed the Pacific Ocean and reached the Philippines in the sixteenth century, they encountered ferocious resistance from Muslims inhabiting the Southern Sultanates of the country. This reminded them of their ancient enemy, who aside from being Islamic, was hostile like the Moors. Thus the Philippine Muslims were called "Moros.",

The Muslims' historical claim on Mindanao and Sulu as their homeland predates the Spanish colonization of the Philippines that began with the arrival of General Legazpi in 1565. About 200 years prior to colonial rule, local Islamic communities and settlements were already thriving in Sulu and Mindanao. There were three established sultanates-Jolo (seat of the first Muslim sultanate), Sulu, and Maguindanao-long before the Spaniards consolidated their control over the northern part of the Philippines. Trade and commerce by Muslim traders across the Malay regions and beyond were also flourishing.

According to a 1573 Spanish record, three Muslim settlements in their nascent stage were found in Luzon. ${ }^{5}$ This signifies the rising influence of Islam in the country that could transform the entire archipelago into a Muslim nation similar to its neighboring countries. Clearly, Spanish colonialism in the sixteenth century aborted 
the spread of Islamic proselytization activities and reversed the trajectory of Islamic diffusion in the country.

As the Spanish monarchy claimed sovereign rule over most of the lands of the indios (from the word india, meaning "native"), it failed to claim sovereignty over the territories of the Moros. The Muslims offered a good fight to check the colonizer's attempt to annex the Moro homeland under the Spanish Crown. While the wars between the Spaniards and indio conscripts on the one hand and the Muslims on the other hand were religious in character or had religious undertones, opposition to Spanish rule failed to transcend ethno-linguistic identities of native Muslims to a national and transcendental Moro identity comparable to the transformation of indio (Hispanized, subjugated, and Catholicized) into a Filipino national identity years before the spark of the 1896 Revolution. ${ }^{6}$ Historical evidence was patchy and insufficient to conclude that a Moro nation was created as a result of Muslim resistance against colonial rule. In fact, in spite of the considerable success of Muslims to repel the incursions of Spanish conquistadores, they were not able to rise above their limited ethno-linguistic identification.

In a general sense, there was neither a unilateral nor single response to Spanish colonialism among Muslim communities. ${ }^{7}$ McKenna challenged the idea that aggressive Christianization precipitated a heightened Islamic consciousness and identity of the Muslims. ${ }^{8}$ A sense of "Moro-ness" among the Muslim populace cannot be attributed to the harsh and ruthless governance of the Spanish regime. It was during the less than half a century of American colonial regime rather than the more than three centuries of Spanish rule when Moro developed into a transcendent and self-conscious Philippine Muslim ethnic identify. 
Najeeb Saleeby, one of the most influential thinkers in the early American colonial administration, expressed in his 1913 essay, The Moro Problem, that the various Muslim ethno-linguistic groups were in no sense united, nor possessedjointly or individually — a politically potent oppositional Islamic consciousness.

Acknowledging the value of imparting a sense of collective development and common "destiny" among the Moros, Saleeby suggests that Moros be allowed to emulate a "superior" culture analogous to that devised by the Americans for Christian Filipinos.

Moved by a natural tendency to imitate superior civilization, he would unconsciously reform his customs and home life and gradually acquire American ideas and new ambitions. An enlightened Moro community, wisely guided by efficient American officials, would undoubtedly work out its own destiny, and following the natural law of growth and development would gradually rise in wealth and culture to the level of a democratic municipality. ${ }^{9}$

Saleeby laid down the colonial genesis of Morohood. Foremost was his campaign for a datu-led development and unification of the Philippine Muslims through the formation of a new transcendent Muslim identity-the transformation and fusion of Muslim ethnic identities into a single Moro identity. Second was to intensify and deepen people's understanding as well as appreciation of Islam as their religion. And third, the precipitation of social osmosis to enable the Moros to acquire the level of economic and political development the Americans have bequeathed to Christian Filipinos.

In spite of America's fierce pacification operations in the Muslim south, that took longer and applied more cruel methods compared to the northern rebels, benevolence was also pronounced. ${ }^{10}$ The Muslims and other non-Christianized groups in the country were treated as "wards" of the nation who needed the state's protection and 
additional tutelage to bring about "their advancement into civilization and material prosperity." 11 As Abinales assays, a number of Muslims have made their relationship with Americans intimate and highly personal while more politically astute datus have established a long relationship with the new colonizers in the hope of soliciting political benefits. $^{12}$

Markedly, the promotion of American-type education and institutionalization of public school system in the entirety of the Philippines hastened the growth and formation of Muslim identity as Muslim Filipinos. Apart from the influence of American system of education that produced new Western-oriented and educated Muslim elite, the policy of secularization has led, to a significant degree, the rationalization of Muslim political system.

In McKenna's review of US policies towards the end of American rule, he says:

... American colonial policies had the effect of ethnicizing Muslim identity in the Philippines. By "ethnicizing" Islam I mean to say that American colonial rulers encouraged the development of a self-conscious Philippine Muslim identity among a generation of educated Muslim elite who were otherwise divided by significant linguistic, geographic, and, to some extent, cultural barriers. ... [a]s the term "Moro" remained a pejorative among Philippine Christians, the most common alternative denomination became "Muslim Filipino," connoting a Muslim citizen of the new (or soon-to-be) Philippine nation. ${ }^{13}$

Cognizant of the imminent granting of Philippine independence by the United States in 1946, Muslim politicians tried to project the image of a unified and revitalized populace in order to gain some power bases in a nation-state that will be controlled by Christian Filipinos. The amplification of a self-conscious transcendent identity as Philippine Muslims resulted not from their opposition to American 
colonial rule but adherence to the objectives of western-defined development and ideals of secularism.

\section{The Search for Moro Identity and Nation-State}

The quest of Muslims of Mindanao to create their own sovereign state started when the entire Philippines was still a colony of the United States of America. Beginning in early 1920s, Muslim leaders of Sulu and Mindanao began a peaceful movement that asserted their right to establish their own nation-state and form a government of their choice. Leaders petitioned and offered two options for the US Congress to consider: join the Federal Government of the United States, or be declared a separate sovereign

state from the would-be Republic of the Philippines. ${ }^{14}$ Being part of the Philippine state was not among their alternatives.

The denial of their petition and inevitability of Philippine independence after an American sponsored 10-year transition period under a Commonwealth Republic led Muslim leaders to reconfigure their Moro identity in line with forthcoming Philippine nation-state. Muslim leaders declared themselves as "Filipinos" and considered Moro-pejoratively associated with piracy, savagery, slavery, treachery, amok (juramentado), and other negative connotations-as a name that is unacceptable.

In the 1934 Constitutional Convention that framed the 1935 Philippine Constitution (used as the fundamental law of the Commonwealth and 1946 Republic of the Philippines), several elected Muslim Constitutional delegates, led by Alauya Alonto, called upon their fellow delegates not only to cease from calling Muslims as Moros but also to accept Muslims as part of the Filipino nation. Alonto of Lanao henceforth declared:

We do not like to be called "Moros" because when we are called "Moros" we feel that we are not considered as part of the Filipino people... So that I 
would like to request the members of this Convention that we prefer to be called "Mohammedan Filipinos" and not "Moros," because if we are called "Moros" we will be considered as enemies [of the state] ... ${ }^{15}$

The turn of events is a classic case of shifting self-definition, attaching new value and meaning to one's identity in the prospect of advancing its political interests and exigencies of power within the parameters of a newfound state.

The intensification of ethnicized Muslim identity continued after the Americans left. Although Islamic education from early 1950s until late 1960s was geared towards the deepening of Muslim consciousness, it underscored the value of "good citizenship" and emphasized the importance of political participation of Muslims in the affairs of the Philippine Republic. Domocao Alonto of Lanao, a Muslim member of the House of Representatives, proclaimed before the First National Muslim Convention in 1955: "We need a thorough spiritual rejuvenation ... If we are good Muslims, we are automatically good citizens."16

What deepened in almost two decades from the 1950s was the ethnic selfrecognition of the masses as Filipino-Muslims (foremost as a Filipino and second, as a Muslim). The legitimacy of the Philippine state to govern the Muslim areas of the country was neither questioned nor challenged by any of the Muslim elite.

\section{From unity to disunity}

In late 1960s until early 1970s, a string of political events transpired that triggered the re-invention of Muslim identity. The emergence of new intellectuals and counter-elite among the Muslims revived the independence movement of the 1920s, momentarily suspended by the 1946 Philippine independence.

The violence of the state in the infamous Corregidor Jabidah massacre on 18 March 1968, ${ }^{17}$ almost 50 years after the peaceful clamor for independence, re-sparked 
the issue of Muslim sovereignty, this time through war. The massacre, otherwise known as the "Corregidor Incident," took place when 28 out of less than 200 Muslim military trainees (called “Jabidah commandos"), mostly Tausug and Sama from Sulu and Tawi-Tawi, were summarily executed in Corregidor Island. ${ }^{18}$ Notwithstanding a few Senate and Congressional hearings on the issue, no one was arrested and held responsible for the ghastly massacre. ${ }^{19}$

The Jabidah massacre was perceived as the state's assault against Muslims who offered their services to the Republic, but had been duped, subjugated, and perfidiously murdered by Christians acting on behalf of the state. Both Muslim political elite and traditional leaders have experienced the contradictions in their hyphenated identity and felt the frustrations in their bid to be integrated in the body politic.

The tragedy gave birth to the Muslim (later renamed Mindanao) Independence Movement (MIM) led by Datu Udtog Matalam, then Governor of Cotabato province (the biggest in the country at that time). Matalam's call for "secession" came in the wake of political violence in Cotabato that was then beginning to take shape as a Muslim-Christian conflict. ${ }^{20}$ However, he relinquished his idea of secession soon after then President Marcos co-opted him and later became the Presidential Adviser on Muslim Affairs.

Other Muslim politicians and traditional leaders came together to continue what Matalam had given up. Then member of the House of Representatives, Raschid Lucman formed the Bangsa Moro Liberation Organization (BMLO) in 1971 but later dropped the name Moro, which remains unacceptable to many of the Muslims, and adopted Bangsa Muslimin Islamic Liberation Organization (BMILO) instead in $1984 .^{21}$ Generally composed of Maranao ethnic group, the BMILO was conceived to 
be the umbrella organization of all Muslim liberation forces. ${ }^{22}$ The BMILO braced itself for a protracted armed confrontation with the state in pursuit of its goal to craft a separate Muslim state from the Philippines. Towards this effort, several batches of Muslims participated in a series of military training conducted in Sabah, Malaysia Among those who belong to the first batch, known as the "Top 90," were Nur Misuari and Salamat Hashim. ${ }^{23}$

Nevertheless, the BMILO was not able to sustain itself as an alternative to MIM when some of its key leaders tried to negotiate with then President Marcos for Muslim Mindanao's political autonomy. This was perceived by the younger and more militant BMILO members as a sign of capitulation. The frustration and disgust caused by the leadership, by and large composed of Muslim politicians and traditional elite of Muslim society, led Misuari and Hashim together with a number of young intellectuals of the BMILO to bolt out of the organization and eventually established the Moro National Liberation Front (MNLF).

Gaining lessons from the past Muslim independence movement beginning in the 1920s, Misuari assessed that the failures of previous movements were not wholly rooted in the callousness of the state in its treatment of Muslim minorities and discriminatory policies that favor the Christian majority but also partly caused by the "collaboration" of their own Muslim leaders with the Manila "politico-economic elite." Misuari sets him apart from the rest of the Muslim organizations. He conceived a rebellion that has two fundamental objectives: to set up a single independent homeland covering the 13 ethno-linguistic Muslim groupings in the Philippines; ${ }^{24}$ and to wage war against Muslim traditional politicians and aristocratic leaders who cooperated with the state. ${ }^{25}$ 
Misuari's vision of a secessionist war was emphatically secular in orientation rather than Islamic. It is neither ethnic nor religious. Its goal is to reclaim the Bangsa Moro (Moro Nation), the Muslims' homeland, that has been "unjustifiably annexed by the Philippine state." He called upon his brethren to renounce their identities as Filipino-Muslims and declare their identity and nationality as "Moro," a reincarnation of the pre-colonial identity as the descendants of the "unsubjugated" and "uncolonised" peoples. What looked to be the state's prejudices against the Muslims had found a national expression. As Ernest Gellner says, it is more advantageous to set up a "rival nation" when entry into the dominant nation is difficult if not impossible. $^{26}$

The maiden issue of MNLF's clandestine newsletter, Mahardika, stipulates the meaning of Moro identity and character of Moro struggle. It is national in scope and covers what it imagines to be the confines of the Bangsa Moro-neither ethnic nor religious.

From this very moment, there shall be no stressing the fact that one is a Tausug, a Samal, a Yakan, a Subanon, a Kalagan, a Maguindanao, a Maranao or a Badjao. He is only a Moro. Indeed, even those of other faith [sic] who have long established residence in the Bangsa Moro homeland and whose good-will and sympathy are with the Bangsa Moro Revolution shall, for purposes of national identification, be considered Moros. In other words, the term Moro is a national concept that must be understood as all embracing for all Bangsa Moro people within the length and breadth of our national boundaries. $^{27}$

In retrospect, Misuari transformed the epithet "Moro" into a positive identity of the Muslims and symbol of unity and pride in the course of national resistance against the Philippine state. The ethnicizing of Muslim identity was a consequence of the awakening of Muslim self-consciousness. 
The Bangsamoro struggle is an expression of a "reactive nationalism," articulated by the new and non-traditional counter-elite on a reactive basis, and resonates with Muslim society which is undergoing some "crisis of self-confidence." It demonizes the threats of the state as the enemy and mobilizes the masses to take collection action against such threats. It has to appeal to an educated Muslim middle class and is invariably populist, intended to induct the masses into politics.

Misuari led the MNLF of about 65,000 armed regulars for 30 years in war and peace. The Bangsamoro independence movement was nonetheless saddled with leadership crisis and power struggles. The question of Moro unification has been the overriding concern both of the Muslims and movement's sponsors like the Organisation of Islamic Conference (OIC), ${ }^{28}$ the Muslim World League (MWL), and the Muslim World Congress (MWC).

In 34 years from the time the MNLF was established in $1971,{ }^{29}$ the movement suffered four organizational fissures, a clash over leadership occurred every over eight years on the average. Currently, there are four Moro organizations (varying in size and prominence) advancing the issue of self-determination in different forms and adopting dissimilar strategies. A fifth organization just emerged recently, in February 2005, and engaged the Armed Forces of the Philippines (AFP) in a running battle in Sulu group of islands.

The first split took place as early as 1977, a year after the MNLF and the Government of the Republic of the Philippines (GRP) forged the GRP-MNLF Tripoli Agreement. ${ }^{30}$ Salamat Hashim (a leading member of MNLF Central Committee), a devout Muslim Maguindanaoan, broke ties with the MNLF and formed the "New MNLF" which advocated for autonomy rather than independence. Hashim projected his newfound organization as a reformist party that can deal with the government 
better than the MNLF. When the OIC maintained its backing to the MNLF, the New MNLF changed its name to Moro Islamic Liberation Front (MILF) in 1984, and made Islam as its official ideology. Hashim challenged Misuari, a secular and nationalist, as the rightful leader of the Bangsamoro. He chaired the MILF until his death on 13 July 2003.

The MILF's armed force, the Bangsa Moro Islamic Armed Forces (BIAF), has about 120,000 fighters (80 percent are armed) and 300,000 militiamen in late 1990s. ${ }^{31}$ Even though the AFP puts the MILF strength to be between 8,000 and 15,000, it does not deny that rebels ranks swelled by 14 percent in the first six months of 1999 and 11 percent in terms of firearms in the same period. MILF's military might has seriously confronted government forces in Mindanao from the time the MNLF became part of the Autonomous Region in Muslim Mindanao (ARMM) ${ }^{32}$ in 1996 in line with the provisions of the GRP-MNLF Final Peace Agreement (FPA). ${ }^{33}$

The second split happened in 1991, two years after the creation of the ARMM in 1989, with the founding of the Abu Sayyaf ("sword bearer") Group or ASG by Abdurajak Janjalani. Like Hashim, Janjalani was a pious leader who studied Islamic law in Saudi Arabia but more radical compared with Hashim. He received his military training in Libya and fought in the 1979-1989 Afghanistan war against the Russian invasion. He was later killed in an encounter with policemen in 1998 and ASG's leadership was assumed by his brother, Khadaffy Janjalani (thought to be the titular head). While the ASG shares the same disillusionment with the MILF with regards to MNLF's cooperation with the government, it nonetheless differs with the MILF in its vision of an Islamic state and the manner it can be realized. The ASG advocates the creation of a "purely Islamic government" through "Jihad Fi-Sabil-lillah" (Islamic 
war) to end "oppression, injustice, capricious ambitions, and arbitrary claims impose on the Muslims."34

Mainly composed of young and disgruntled elements of MNLF and MILF and largely composed of Tausug and Sama ethnic groups of the Muslim community, its military strength is estimated between 300 and 1,000 armed guerrillas with roughly 400 firearms. ${ }^{35}$ It has been known for its hostage-taking and kidnapping for ransom, robberies, beheadings, and other ghastly acts that victimized both Muslim and Christian civilians. The MNLF and MILF view the ASG with consternation and dismay. The MNLF had given tacit support to the AFP military action against the ASG while the MILF renounces its activities and calls it a group of bandits that have given Islam a bad name. ${ }^{36}$ The U.S. and Philippine governments have classified the ASG as a "terrorist organisation" and pursue a policy of "search and destroy" without any inclination of forging a peace agreement.

The third faction was formed in the early months of 1995 , prior to the conclusion of the 1996 peace accord between the GRP and MNLF. Known as the National Islamic Command Council (NICC), under the leadership of Melham Alam (former chief of staff of Misuari), it claims to have nearly 90 percent of the original 20,00025,000 MNLF forces. The military, however, estimates its membership to few hundreds. In a press conference held in March 2000, it announced that the guerrilla war against the Philippine government would continue and accused Misuari as a collaborator of the Christian state and a traitor to the Bangsamoro liberation struggle. The NICC further pronounced the establishment of an independent Islamic state in Mindanao through "mutual destruction." Given the relative similarity between NICC's and ASG's belief and mode of struggle, there is a strong indication that both 
of them have been working either collectively or separately in staging terrorist acts against Christian and Muslim civilians masquerading as political engagements.

The fourth fracture came seven months before the ARMM election in November 2001. Led by his comrade-in-arms in the MNLF and ARMM, calling themselves as the "Council of 15," ${ }^{37}$ Misuari was declared as "incompetent" to remain as MNLF's Chairman and euphemistically elevating him as "Chairman Emeritus" instead. This effectively rendered him powerless. Through a resolution it issued on 29 April 2001, the Council proclaimed itself as the legitimate Central Committee of the MNLF. ${ }^{38}$ This was eventually acknowledged by the Philippine government and OIC's 10th Summit Meeting on 15 October 2003 held in Putrajaya, Malaysia as the sole "representative of Muslim community in the Philippines." 39

Likewise, Misuari was ousted as ARMM Governor and Chair of the Southern Philippines Council for Peace and Development (SPCPD) ${ }^{40}$ which he jointly held for five years (1996-2001). Following his expulsion, Misuari was incarcerated on charges of sedition ${ }^{41}$ and corruption ${ }^{42}$ filed against him in court by the government. The "Council of $15 "$ had consolidated its power with the election of Parouk Hussin, former Foreign Affairs Committee Chair of Misuari and one of the leaders of the "Council," as the new regional governor in November 2001, notwithstanding the political and financial support of the national government in the electoral campaign. Hussin serves as governor under the new ARMM's Organic Act (Republic Act $9054) .^{43}$

The fifth group surfaced in February 2005. The military named it as "Misuari Breakaway Group" (MBG) or "MNLF renegades," to distinguish it from the “mainstream MNLF" which had been part of government in 1996. It was tagged as an assemblage of terrorists linked to the ASG. Contrary to what the military claimed that 
the group demanded the speedy and fair trial of Misuari who was imprisoned under charges of treason and corruption, its spokesperson, Ustadz Habier Malik, cited AFP's atrocities in Sulu as the main triggering factor for the uprising. The Misuari factor or loyalty to any individual never figured as the cause in the most recent violence in Mindanao. $^{44}$

Factionalism in the Bangsamoro struggle, either among and between traditional political elite or new intellectual and counter-elite, has not only hobbled the quest of the Moros towards achieving their goal but more importantly, highlighted the fundamental and continuing question of Moro identity and Moro national unity. From Matalam's MIM to Hashim's MILF, Muslim minorities find it difficult to unite under one self-identifying and all-inclusive banner. As a consequence of constant divisions and splitting up of leaders in the Moro movement, the process of ethnicizing Moro identity as a nationality has been stunted and is a reflection of a crisis in selfdefinition.

\section{The continuing formation of Moro identity and national unity}

Although heads of organizations refer to the same "national past," the "national future" is indeterminate and blurred. The internecine debate over the concept of a Bangsa Moro and strategy in achieving the vision of a separate state is far from being resolved. The Moros speak of different Bangsas. The erstwhile secessionist MNLF says the Bangsa covers the 13 provinces and nine cities in Mindano, Palawan, Sulu, Basilan, and Tawi-Tawi, while the MILF declares that it shall comprise the geographical areas dominated by the Muslims (six provinces [Maguindanao, Lanao del Sur, Lanao del Norte, Basilan, Tawi-Tawi, Sultan Kudarat] and the city of Marawi). This shall constitute domain of the future Moro nation-state. The ASG and other splinter groups have nebulous concept of Bangsa Moro. In other words, there is 
no single idea of a Bangsa Moro among the Muslims asserting their right to selfdetermination. Apparently, the notion of a Moro Nation is constricted by their assorted political and organizational agenda.

Moreover, ruptures in the Bangsamoro movement occur whenever the state accommodates some of the political demands or acquiesces partly to certain grievances advance by a particular Moro revolutionary organization. It appears that the shifting loyalties and interests of leaders as well as their respective organizational strategies and tactics is more of a response to the vagaries of political priorities and constraints which the state presents.

It is also instructive to note that the three major rebel fronts that contested state's power since the Jabidah massacre of 1968 correspond to the three main ethnic groups among more than a dozen of Muslim ethno-linguistic groupings. The BMILO was generally composed of the Maranaos, the MNLF by the Tausugs, and the MILF by the Maguindanaos. It was also reported that Moro rebels prefer to fight with their fellow ethnic groups, e.g., Maranaos, Tausugs, and Maguindanaos, rather than to be with ethnic groups other than their own. ${ }^{45}$ This does not connote however that feeling of enmity and hostility exists between ethnic groups.

Similarly, there is no convincing proof that links the organizational split among rebel groups to inter-ethnic competition or animosity. The fact remains that both MNLF and MILF to date are composed of Moro multi-ethnic fighters who are generally united in pursuing their particular organizational objectives rather than divided by internecine ethnic identities. Nevertheless, there is ample confirmation to suggest that both organizations shift their strategies and tactics based on the configuration of state and character of regime that interacts with them. 
Indeed, the "national character" of the Moro struggle has yet to be strengthened. Its weakness is portrayed not only in terms of the Moros historical difficulty to stand as one people united under a single leadership that effectively engages the state into a vision of self-governance but also in categorically defining and qualifying the national identity of people. Moro identity is far from dense and vulnerable to political manipulation either by the state or non-state actors as witnessed by the formation of innumerable groups, some of them involved in criminal activities, using "Islam" as their protective shield.

In spite of the aforesaid infirmity in Moro's identity, affinity with Muslims (regardless of ethno-linguistic grouping) has persisted. Identities have not dissolved and primordial interests have been sustained. They were seldom surrendered to the imposing power of the Philippine state. Ethnic ties have emotional, psychological, and religious depths that are not easily severed. These are human ontological factors which cannot be subjected to authoritative controls; thus, no amount of coercion or repression can contain Moros aspirations to self-determination in an extended period of time.

The dual dimension of Moro identity indicates its strength and weakness. While Moros have not transcended their innate ethno-linguistic identity, this has not prevented them to work and relate with other ethnic groups amicably—both Muslim and Christian. This is attested by the presence of Christians and Muslim converts in several armed and unarmed Moro organizations. The cultural boundary has been permeable and spongy. On the other hand, the less than orthodox practice of Islam among Filipino Muslims, ${ }^{46}$ in contrast to Muslims of Middle Eastern countries, gives the Moros the opportunity to deepen their sense of oneness and nationhood through a 
more tolerant manner and process of consultation and consensus with other competing Moro revolutionary organizations.

\section{The State and Moro Right to Self-Determination}

In spite of the inability of Muslims to transcend their ethnic identities in peace and war, the quest towards building a Moro nation-state continues. Saleeby's observation on the issue of Muslim unity in the early years of American colonization and Misuari's effort to ethnicize Moro identity in the late 1960s and early 1970s have not been translated into reality. Nonetheless, as the stringent objective conditions of nationhood have yet to be met, the vision and subjective notion of creating a Bangsa Moro kindles in the minds and hearts of Philippine Muslims.

In the process of realizing the so-called Bangsa Moro Republik, amidst the arduous task of surmounting and raising ethnic identities and loyalties to a level of Moro national consciousness, the MILF continuous to be and now the most potent armed organization in carrying out the Moro secessionist movement. The government has acknowledged the armed capability of its forces to threaten the territorial integrity of the state after the MNLF acceded to political autonomy as defined in the Philippine 1987 Constitution (Sections 15-21, Article X). Such recognition prompted it to initiate and commence the process of forging a peace accord with the MILF, beginning with informal negotiations, even before the conclusion of the 1996 GRPMNLF FPA.

On 18 July 1997, then President Ramos was successful enough to bring the MILF to the negotiation table. The GRP-MILF Agreement for the General Cessation of Hostilities (AGCH) was signed but failed to yield any substantial results. Armed hostilities between government and MILF forces intensified under then President 
Estrada's "All Out War" policy against the MILF in April 2000 and completely disregarded even the 1998 General Framework of the Agreement of Intent (GFAI) ${ }^{47}$ between GRP and MILF peace panels inked under his own administration.

Seven years after the signing of the AGCH, now under President Arroyo, the GRP-MILF negotiations, though resumed in 2001 through the signing of the General Framework for the Resumption of Peace in Kuala Lumpur, Malaysia, have yet to be concluded. The Tripoli Agreement of Peace of $2001^{48}$ that defined three major agenda items of security, rehabilitation, and ancestral domain has been limited to exploratory talks rather than on the discussion on the aforesaid agenda. ${ }^{49}$ Likewise, the GRPMILF Peace Talks in 2003 have not been too fruitful. Negotiations have been entirely focused on making ceasefire agreements more respectable and implementable as these have oftentimes been breached rather than applied. Generally, the peace talks have been highly volatile, tenuous, and insubstantial; limited to ceasefire agreements and presently the process had run longer than the 1992-1996 GRP-MNLF talks.

In 2004, attempts were again made to contain armed clashes between the GRP and MILF forces to enable both panels to commence the discussion on the more substantive issues behind the 26 years of MILF secessionist struggle. In spite of the pronouncement of government in late August 2004 that the GRP-MILF peace negotiations are on track, ${ }^{50}$ armed conflict has yet to cease considerably.

On the part of the Philippine state, the defense and preservation of its territorial integrity at all costs (armed and unarmed) persists as its primordial interest. Gaining the support of the OIC, the Association of Southeast Asian Nations (ASEAN), and presumably, the United Nations, the Philippines maintained that any attempts that will alter the country's political and geographical jurisdiction will have to be done within the constitutional framework and processes of the country. Hence, MILF's ultimate 
agenda to secede, as what the MNLF began in 1971, is a non-negotiable subject in the GRP-MILF peace talks.

On the other hand, while the MILF recognizes peace negotiations as the only "peaceful, civilized, and democratic way of solving the Bangsamoro problem," repeatedly emphasizes that independence should be the main agenda and framework for the formal talks. "There is no point to proceed if the negotiations will not lead to independence," declared the MILF negotiators. The late MILF Chairman Hashim believed that what the GRP-MNLF FPA resolved was the government's problem and not the Bangsamoro problem, "the agreement never touched the core of the Bangsamoro problem which is the illegal and immoral usurpation of their (referring to the Moros) ancestral homeland and legitimate rights to freedom and selfdetermination". ${ }^{52}$ Hashim's successor, Al Haj Murad, also expressed in a message on the occasion of the fasting month of Ramadhan in November 2003, that "there can be no genuine peace and development unless the right of the Bangsamoro people to selfdetermination is adequately addressed." 53

What makes the right of self-determination so difficult to clarify is that its exercise involves a clash of fundamental world order principles. On the one side is the principle of upholding the territorial sanctity of existing states. On the other side is the sense that peoples have the right to statehood. Articles 1 (2) and 55 of the United Nations Charter have embodied the principle of self-determination as one of its guiding philosophies. The Universal Declaration of Human Rights (UDHR) pursued the issue further by stating that self-determination is not simply a principle but a right of everyone to "liberty." The International Covenants on Human Rights-The International Covenant on Economic, Social, and Cultural Rights (ICESCR) and the International Covenant on Civil and Political Rights (ICCPR)—specifically provide in 
Article 1 of each that "All peoples have the right of self-determination. By virtue of that right they freely determine their political status and freely pursue their economic, social and cultural development., ${ }^{, 54}$

However the adoption of the 1960 Declaration on the Granting of Independence to Colonial Countries and Peoples (DGICCP) in the form of a General Assembly Resolution is instructive. It confirms the right of self-determination in relation to colonialism and denies some forms of the right's wider application. Evidently, it appreciates the inevitable tension between the exercise of the right to selfdetermination and the parallel set of rights associated with territorial integrity of existing and emerging sovereign states. Thus, it reiterates Article 1 of the ICESCR and ICCPR in its Operative Provision 2 but at the same time qualifies such right in its Provision 6 which reads: "Any attempt at the partial or total disruption of the national unity and the territorial integrity of a country is incompatible with the purposes and principles of the Charter of the United Nations. $" 55$

Provision 6 of the DGICCP culminated in the adoption of the influential Declaration of Principles Concerning Friendly Relations Among States (DPFRS) in 1970 as United Nation's General Assembly Resolution 2625. The resolution accepted the principle of the right of self-determination that is linked to the notion of "equal rights of peoples" but cautioned that the right shall not be construed as

authorising or encouraging any action which would dismember or impair, totally or in part, the territorial integrity or political unity of sovereign and independent States conducting themselves in compliance wit the principle of equal rights and self-determination of peoples ... and thus possessed of a government representing the whole people belonging to the territory without distinction as to race, creed or colour. ${ }^{56}$ 
The assurance of territorial unity is now made contingent on the government being representative of the whole people and non-discriminatory in relation to "race, creed, or colour" and full right of self-determination (including secession) pertains only in colonial situations.

In the international law literature on self-determination, two main views are pulling in opposite directions. The first tendency is the more restrictive view which limits the exercise of the right of self-determination within the confines of the territorial jurisdiction of existing states; the right cannot be invoked if the territorial unity of the state will be transgressed. The second view is expansionary which acknowledges and, to varying degrees, validates recent state-busting practice in a reformulated legal approach that admits that the character and scope of the right are more unsettled than ever. This latter view takes due note of the degree to which nonsovereign territories of the Soviet Union, Yugoslavia, and Czechoslovakia were given diplomatic recognition and admitted to the $\mathrm{UN}$ as sovereign states.

The controversy on the principle and right of self-determination has led peoples and states to armed conflict. Struggles for autonomy and secession on the defense of peoples' national rights are politically and militarily confronted by the state, invoking its right to protect the inviolability of its territory. Peoples of the world are told they have the right to self-determination. Nevertheless, if this right is suppressed by a sovereign state, the international community supports territorial integrity until a war of independence is successful. As in the past, the entire problem is settled on the battlefield. The conflict has been the source of tremendous human suffering and destruction in Asia, Africa, and Europe

By and large, the conflict behind self-determination struggles is fundamentally a question of territorial rights. In war and peace, the issue of one's control over a 
physical space has been the persistent bone of contention between the Philippine state and the Bangsamo independence movement. In an effort to pursue the "selfdetermination" agenda in the GRP-MILF peace talks, the MILF pushes its concern over ancestral domain. It hopes that government's recognition of the right of the Bangsamoro over their ancestral domain will eventually result to the acknowledgement of Moros' territory. "We just want a physical space where we can freely practice our religion and apply our ways of life. There is no need to seize power," says MILF Information Chief, Mohagher Iqbal. ${ }^{57}$

Indeed, the linkage between Moro identity and territory is intricately intertwined. Poulantzas, emphasizing the importance of territory to the notion of group self-identity, refers to the "historicity of a territory and territorialization of a history"-a territorial tradition concretized in the homeland. ${ }^{58}$ Therefore, a territory by itself is a human construct which serves as the material basis in defining and re-defining human, group, ethnic, and social relations. It is the source of one's social security, assistance, dependency, sociability, and intimacy. It assures the continuity of culture and endurance of collective memory of peoples. As such, the concepts of space and territory are of extreme importance in ensuring the tenacity of one's identity and survival as a people.

The absence of or restriction to such control may invariably threaten the fulfillment of the peoples' rights and imperil their identity to a particular territory. In this respect, the anxiety of the Bangsamoro over the future of their homeland simply infers their lack of full control over their lives. The right of a group with a distinctive politico-territorial identity to determine its own destiny is the political translation of aspirations in the demands for self-determination. Judge Hardy Dillard of the International Court of Justice (ICJ), writing in a separate opinion on the Western 
Sahara Case, says that: "It is for the people to determine the destiny of the territory and not the territory the destiny of the people." 59

One of the most vital reasons in exercising control over a piece of territory is that it reifies power. Tillich points out:

Being means having space or, more exactly, providing space for oneself. This is the reason for the tremendous importance of geographical space and the fight for its possession by power groups. The struggle is not simply an attempt to remove another group from a given space. The real purpose is to draw this space into a larger power field, to deprive it of a centre of its own. ${ }^{60}$

In as much as ethnic identity is, above all other things, territorial identity, the issue of Bangsamoro homeland has been the crux of the MILF's self-determination struggle. In fact, the subject of ancestral domain will be the main agenda in the next round of discussion in late 2005 between the GRP and MILF negotiating panels. This would likely be a thorny issue and could lead to another stalemate.

At the onset, the government perceives the question of ancestral domain within the bounds of the 1997 law: the Indigenous Peoples' Rights Act (IPRA) or Republic Act 8371. IPRA seeks to recognize, protect and promote the right of indigenous peoples and cultural communities including Muslims, to claim ownership over their ancestral domain pursuant to the 1987 Constitution. It hinges on the concept of stewardship or the right of indigenous peoples to be the guardians and custodians of the earth. The law further sustains the Regalian Doctrine-affirmation of the state's ultimate right to own, develop, and utilize all lands and resources under its political jurisdiction as enshrined in Section 2, Article 12 of the Constitution. By invoking the inherent power of the state to eminent domain, it reserves its right to have the last word on ancestral domains. 
In contrast, the MILF works within the notion that the right over their ancestral domain is none other than the right to their homeland-the Bangsamoro territory, believed to have been "illegally annexed by the state." It is not only about claims and rights to obtain ancestral domain titles as what the IPRA promises, but the right to self-determination and a correction of historical injustices.

The MILF regards ancestral domain as the issue, which could give substance to the self-determination struggle. The government, on the other hand, considers it a question that can be answered within the bounds of the state's power and authority. The differences of perspectives and frameworks of mind in viewing the issue of ancestral domain could be a tough concern in the upcoming negotiations but not necessarily insurmountable.

\section{Beyond National Self-Determination: Examining the Moro-State Conflict}

The contradiction between the state's nation-building project and the secessionist movement's state-creation venture has not only led to armed conflict but also tested the viability and competency of the current Philippine political system in unifying the country given the diversity of its people. Thus, beyond the issue of self-determination, a crucial element that contributes to the mitigation or exacerbation of the current conflict is the manner the state governs.

In Kofi Annan's address to the UN General Assembly in 1999, the SecretaryGeneral probed on the right of any state to hide behind sovereignty while committing flagrant violations of human rights. He argued that "the state is now widely understood to be the servant of its people-and not vice versa." Invoking the UN Charter, Annan called upon states to protect and safeguard human rights and fundamental freedoms of each and every citizen. ${ }^{61}$ Interestingly, in 1997, Prince Hans 
Adam II of Liechtenstein presented a similar standpoint in his exposé "Democracy and Self-Determination," where he made the case that the state should principally offer services to its citizens; they in turn should have the right to "choose their states and citizenship freely-in self-determination.",62

Against this backdrop, it is worth examining self-determination from the perspective of individual or group quests for human rights and better governance rather than a collective struggle for national independence. In other words, the search for a nation-state that is more responsive and relevant to the needs of people who are culturally distinct from the others, oftentimes the majority, is contingent more importantly on the character, ability, and capacity of the state to make itself a "servant of its people" rather than simply a ruler of its people. The so-called "internal' dimension of self-determination, as what Prince Hans Adam II alludes to, is as essential as to the right to one's statehood.

In as much as peoples' right to "internal" self-determination is hinged on the legitimate claim of the minorities to cultural and political autonomy, it becomes imperative that the grounds and sources where such demand springs from be analyzed. This part of the article is thus intended to assess the deep-seated causes of the Moros' self-determination struggle.

Without underrating the ethno-religious grounds of secessionism, it is contended that the separatist movement in Mindanao has been prolonged because of three major causes. First, the low degree of political autonomy which would enable Muslims to protect, safeguard, and defend their culture, identity, language, ways of life, and religion. Second, the inability of the state to adequately meet the basic socioeconomic needs of the Muslim community. Third, the widespread belief among Muslims that they have been victims of the state's systematic socio-cultural 
discrimination and politico-economic exploitation, an impression that has been reflected in the present-day economic, political, and social marginalization of the people.

\section{Low degree of political autonomy}

Under the unitary governmental structure, the so-called "autonomy" enjoyed by the ARMM has been historically an illusion. Devolution of powers manifests itself in the formal powers or administrative arrangements that are purportedly decentralized but politically controlled or influenced by the central government. In spite of the pronouncement that the government promotes "unity through diversity," policies have been centrally formulated and conceived with less regard to the heterogeneous requirements, needs, and demands of local communities especially the minority peoples. They have been historically discriminated partially or totally in terms of the quality public services and goods received, degree of affinity to the country, and the amount the concern manifested by the national government to their plight.

The present political governance structure has not only rendered the Moros and other minority groups powerless but also excluded them as part of the Filipino nation. The lack of power sharing due to the concentration of political powers on the few ruling elite either from the central government in Manila or Mindanao's regional administrative centers has been a constant source of discontentment and frustration of people in the periphery. The increased despair, misery, and frustration especially for those people in the most marginalized communities and regions in Mindanao have fuelled armed uprisings.

The assimilationist policy has been manifested through the centralism exercised by the state in the post-colonial period by means of its strategies such as: the emphasis on center-oriented allocation of resources; center-oriented administrative system 
whereby the government exerts control over all other parts of the country, including the peripheral areas inhabited by ethnic groups; and provision of regional and local autonomy which allows peripheral areas to govern themselves and participate in the decision-making at the centre in accordance with the government's pre-defined rules and procedures. Such policy, however, has been seen as inappropriate and resisted by those groups who do not see themselves as part of the nation thereby felt strongly against the erosion of their self-identity and sensed it as a gross violation of their political and economic rights.

Democracies, as well as governmental structures have to tolerate the widest possible diversity so long as the political system remains in equilibrium. In a similar vein, constitutional framework and development strategies apropos of fostering cultural pluralism have to be discovered sui generis in each case. In all respects, it becomes evident that building a nation in a multi-ethnic society through the centralized power of the state will simply result to internecine conflicts. Nation-building thus requires the empowerment of diverse ethnic communities and recognition of their right to nurture their own development as defined by their culture rather than by the state.

The failures of the ARMM and previous "autonomous regions" created in $1977^{63}$ to empower and uplift the living conditions of the Muslims have made MILF less optimistic. Arroyo's proposal for a more “enhanced, expanded, and strengthened autonomy" under the draft GRP-MILF Final Peace Agreement was shrugged off. It is a "tired phrase" states Michael Mastura, one of the members of the MILF negotiating panel. ${ }^{64}$ Aquilino Pimentel, a senator from Mindanao says that the "proposed peace pact tries to deal with the effects, not the causes, of the war in Mindanao." ${ }^{\circ 5}$ He then 
suggests a federal structure of government to address the problem of the BangsaMoro rebellion and bring a lasting peace in Mindanao.

As a consequence of the top-down approach in development, Mindanao's economic growth path has been altered minimally throughout the post-colonial years. Its economic performance since the country's independence has always been relegated to the role of being an agricultural products supplier, typifying the classic dependency function of being the satellite of the country's major urban and metropolitan centers. It has the least access to basic services and infrastructure and has the highest and constant incidence of poverty as the following section shows.

\section{Socio-economic deprivation}

The centralizing power of the state also failed to uplift the socio-economic and health

conditions of the Muslims. While Mindanao is rich in natural and human resources, ${ }^{66}$ the people languish in destitution and suffer from the quagmire of poverty.

After more than a quarter of a century of Philippine government claims to be "developing" Mindanao, national statistics illustrate the sad reality. Among the 16 administrative regions, ARMM registered the poorest. In 1991, 1994, 1997, and 2000, poverty incidence (proportion of individuals whose annual income fall below the annual per capita) was registered at 56, 65, 64, and 63 percent respectively while national average was placed at 41 percent covering the years 1991 and 1994; 33 percent in 1997 and 34 percent in $2000 .^{67}$ Likewise, out of 81 provinces in the country, Muslim dominated provinces of Sulu, Tawi, Maguindanao, Lanao del, Sur, and Sultan Kudarat were among the poorest in 1997 and 2000 with poverty incidence at 67.1 and 63.2 percent, 35.0 and 56.5 percent; 41.6 and 55.1 percent; 55.6 and 55.0 percent; and 36.6 and 54.3 percent respectively. ${ }^{68}$ 
In terms of indicators in living conditions and provision of social infrastructure, ARMM and western Mindanao need special attention. They have the lowest access to safe drinking water, electricity, and toilet and health facilities. Moreover, Mindanao has the lowest share of the country's health practitioners and visit rates of health personnel. Such deplorable state is reflected in the island's high crude death rates with ARMM having the highest at 9.8 deaths per 1000 people. $^{69}$ In the simple literacy index, ARMM had the lowest in 1994 at 73.5 percent when national average is 94 percent. ${ }^{70}$ Although participation rate ${ }^{71}$ for public and private schools at the secondary level showed modest improvements for school years covering 1997-2000, cohort survival $^{72}$ rates are lowest in ARMM and other conflict-ridden areas of Mindanao. The state of human conditions is thus summarized in Philippines' Human Development Index. The 1997 and 2000 figures reveal that eight out of 10 provinces which registered lowest are in Mindanao with six of them largely inhabited by Muslims: Sulu, Tawi-Tawi, Basilan, Maguindanao, Lanao del Sur, and Lanao del Norte. $^{73}$

In virtually all measures of physical and socio-economic well-being, the ARMM is found at or near the bottom of the national rankings. The Mindanaoans, relative to their counterparts in Luzon and Visayas, have the lowest per capita incomes, largest poverty incidence, and least access to physical and social infrastructure as well as basic services despite the teeming resources of their lands and seas. The people, most especially the minority Muslims and other non-Muslim/non-Christian peoples, have yet to benefit from their natural and human wealth.

The marginalization of Mindanaoans in general and Muslims in particular from the orbit of Philippine development is historically rooted in the colonial and postcolonial land settlement and migration policy which gradually dispossessed Muslims 
and other indigenous peoples of Mindanao of their traditional and ancestral lands. The accelerated influx of Christians from Luzon and Visayas in the "land of promise" particularly in the post-colonial period did not only change the demographics of Mindanao but also altered the concept of land ownership.

The institutionalization of the state's Torrens titling system, which recognizes individual land ownership, contradicted the traditional concept of communal ownership observed and practiced by Muslim and other indigenous communities. The state's recognition of individual land ownership, evidenced by one's possession of a Torrens Land Title, thus tended to favor Christian settlers who were more literate and adept in using the law to their advantage compared to Muslim and non-Christian/nonMuslim who were ignorant of the laws and incapable of using the legal processes involved in land titling apart from the exorbitant cost it required. ${ }^{74}$ Moreover, it is an anathema to people's culture to have an ancestral land, owned collectively, to be parceled and titled individually to members of the tribe.

The inability of most Muslims and other ethnic groups to claim individual ownership over lands they held since time immemorial through the Torrens Land Title virtually rendered them "squatters" in their own domain. More enterprising Christian settlers and business corporations exploited Muslim and other indigenous peoples' ignorance of the law by collaborating with officials of government engaged in land titling by declaring individual or corporate land ownership of ancestral lands by way of "manufactured" Torrens land titles. While some wealthy migrants and private corporations (both local and multinational) took advantage of people's financial difficulties by pressuring them to sell their lands to the former at extremely low prices compared to the current market price, others simply confiscated lands traditionally held by people either by force or display of a "land title" of dubious origin. The 
corporate intrusions in Mindanao contributed to the massive dislocation and displacement of Muslims and indigenous peoples alike. ${ }^{75}$

Muslims of southern Philippines have been victims of economic development. The wealth of their lands and seas has not been transformed in peoples' material development and progress. These were simply siphoned out of their homelands that served the economic interests not only of Christian settlers but also of foreign multinational corporations. The political order seen as the structure that breeds economic deprivation and social discrimination became one of the rallying causes of some Muslim leaders to undertake the process of self-governance outside of the Philippine system of political administration.

The socio-economic conditions certainly continue to worsen as population increase naturally exerts more pressures on the capacity of traditional sources of revenue and livelihood such as the land, rivers, lakes, and seas within reach of the inadequate local technologies and crafts. As with separatist movements elsewhere, ordinary Philippine Muslims are most likely to fight for or support an armed separatist organization when they are faced with no alternative means to survive the persisting discrimination and worsening living conditions.

\section{Perceived discrimination, injustice, and alienation}

Finally, beyond economic and political grievances, the issue of separatism is one of subjective feelings, of perceptions, and of language - that Muslim minorities are being "summarily discriminated and exploited by the Christian majorities"reminiscent of the Spanish period when the former colonizer drove the wedge between the Christianized indios and "non-believers" (Moros and other tribal groups). Christian prejudices against Muslims were created by the Spanish colonial state as part of its "divide-and-rule" policy. Biases against Muslims were then widespread and 
accentuated with the regular performances of "Moro-Moro," a theatrical play that enacts the defeat of Muslim "villains" in the hands of Christian "heroes," Christians' celebration of fiestas. ${ }^{77}$ This folk-theatre survived until the 1950 s whose repercussions reverberate until now.

The dominant Christian community has not really obliterated the lingering antiMuslim preconception in their consciousness as the name "Moro" designates the shared identity for Philippine Muslims that categorically and pejoratively associated with piracy, savagery, treachery, and other negative connotations. On the other hand, Muslims have kept in their collective memory the innumerable cases when native converts were conscripted to fight the Moros in the interest of the Spanish Crown and the Church. The same policy continued during the American colonial regime, though to a limited extent.

On the other hand, the MNLF and MILF, notwithstanding their ideological differences - the former as more secular while the latter being more Islamic-see themselves as "one people" bound collectively on the basis of a common ancestry, history, society, institutions, territory, and more importantly, religion. As the minority people in a predominantly Christian nation, they perceive themselves as the marginalized, persecuted, and powerless people both politically and economically. Regardless of organizational affiliation, independence remains the underlying essence of political autonomy for Muslim socio-politico movements.

In the recent conflict, historical and predetermined mutual feeling of bigotry and prejudice of Christians and Muslims has oftentimes been used by political leaders to engender or strengthen people's identity in the competition for power and resources. And when conflicts escalate, perceptions and languages are distorted within the warring parties. The distortions are partly spontaneous and partly organized to rally 
the people to engage in warfare, bear the economic burdens, and face the human misery of war. Conceivably, when war breaks out, truth is its first victim.

For instance, the alienation of Muslims and other ethnics (non-Muslim and nonChristian tribes) from their homelands due to acts of outright land grabbing of Christian migrants and private corporations has embedded upon their consciousness the inability of government not only in protecting their economic well-being but also in acting on behalf of the Christians in gradually eroding their identity by allowing them to be driven away from their lands, considered as the repository of their culture. This notion subsequently precipitated and crystallized into the secessionist movement as a cause against Christian aggression. ${ }^{78}$

Moreover, the conflictual situation arises when state's nationalist policies exercised through the institutionalization undue political centralism and unitary policies are perceived to be discriminatory and threatening to minority groups' sociocultural, economic, and political interests. The violent reaction of ethnic minorities against these policies is comprehensible as they endanger their collective survival. Accordingly, the undertaking to secede from the state becomes an inescapable recourse on the contention that separatists do not see a fair chance that their fundamental aspiration and interest, i.e., to be a part of the nation, would be hitherto accommodated under the state's political system.

Given the aforesaid politico-administrative, economic, and cultural causes of the Bangsamoro self-determination movement, it is apparent that the crucial immediate issue is one of participatory rather than secessionist rights.

\section{Conclusion}

This article has argued that the state-Moro conflict is sparked and protracted more by the centralism of the state and inadequate democratic space that limits the self- 
governing power of the minorities, particularly the Muslims in southern Philippines. The tenacity and seriousness of the conflict remains complicated with the unremitting inability of the state to substantially and decisively address, over a long period, its core causes insubstantial political autonomy; socio-economic grievances and deprivation; and perceived injustice, discrimination, and alienation of the people from the mainstream of Philippine political and economic development. The issue boils down to political and economic equity and social justice, the crux of the state's responsibility and kernel of nation's spirit.

It is essential therefore that Moros be drawn within the domain of the state and make them feel that they are part and foremost stakeholder of the Philippine nation. Although ethnic identities and affinities can serve as one's refuge when the primordial culture of Moros is threatened by the state's domineering power, the sense of Moros' separateness as a people can be altered or modified. Perceptions are neither fixed nor permanent. They change as material conditions change; identities and communal interests also change and are equally malleable and pliant as they interact with the power of the state. A dialectical relationship exists between one's perceptions and the actual situation or socio-economic and political setting where one belongs. Perceptions and conditions do influence and transform each other.

As discussed earlier in the article, the multi-ethnic character of the Moro struggle for political autonomy indicates that national identity of the Moros will be primarily contingent on the ability of Moro leaders to transcend the limits of organizational and ethno-linguistic loyalties. The less than orthodox practice of Islam among Moros in the Philippines signifies the high probability of creating a Bangsa Moro in a consensual and harmonious manner between and among contending Moro organizations. 
Yet, the process of reversing such outlooks and feelings of alienation and transcending ethnic boundaries also demand a strategic approach of sustained and indefatigable efforts and commitment on the part of the state towards greater democratisation, meeting the new challenges of mosaic democracy and heterogeneous development. It requires the state to redefine itself and adopt an institutional framework of governance that would allow the expression of democracy in kaleidoscopic forms.

State's nation-building and centralization of power to the nation-state, indeed, resulted in the deprivation of ethnic communities to decide for themselves and the power to govern in accordance with their ideals and aspirations. Obviously, the meaning of democracy is violated when minority groups ${ }^{79}$ lack any reasonable chance to take part in the policy-making process in government on a more or less permanent basis without suffering from the "tyranny of the majority." In other words, the rule of the majority or "majoritarian democracy" in deeply divided societies is likely to be profoundly undemocratic.

Since the post-colonial years the unitary state has worked towards the integration, assimilation, and transformation of multiple ethnic identities into a single national identity - a downward exertion of state nationalism. The nationalism of the state is materialized through the assimilation and integration of minorities into the majority's culture, system of governance, and socio-economic structure. This tends to destroy minority rights and cultures even when there is no conscious intent to do so. State nationalism is henceforth resisted by those groups who do not see themselves as part of the Philippine nation. They feel strongly against the erosion of their self-identity and see it as a gross violation of their political, economic, and cultural rights. 
It is the contention of this article that the threat of national disintegration will continue until an appropriate institutional framework for political governance which can accommodate Mindanao's social and ethnic diversity is ensconced. Apart from reengineering political institutions in Mindanao, there is a need to lay emphasis, at least at the local level, on good governance, the rule of law, improved civil-military relations, accountability of public officials for corruption, and human rights protection. These efforts would, to a large extent, facilitate the early conclusion of conflict, accelerate the process of peace, and find a respectable and honorable final peace agreement between contending forces. More importantly, steps toward this direction would not only strengthen the Philippine nation-state but also considerably extirpate the cause of secessionism.

Whether or not the state would be able to meet the challenges of nation-building and national unity is difficult to surmise at this point. Definitely, there will be no quick fixes and no shortcuts. Wounds that have festered for a long time cannot be healed overnight, nor can confidence be built or dialogue developed while fresh wounds are being inflicted. It is a process that requires special and extra effort on the part of the state to guarantee human rights and uphold the rights of people to their own development.

In as much as conflict is created in one's mind, peace can likewise be a product of one's mind. One of the critical elements therefore in conflict resolution is the conscious construction of a positive outlook towards building a new and better relationship to an erstwhile archenemy. The courage in seeking to come to terms with the past is an essential part of the search for a new way forward.

\section{NOTES}


1 "Moro" denotes a non-Hispanized Muslim inhabitant in the "unsubjugated" southern islands, in contrast to "Filipino" (collectively referred to as "indio" until 1872) which symbolises the Christianized, Hispanized, and subjugated people of the Philippines. For an account of the historical development of the Moro identity, see J. L. Phelan, The Hispanization of the Philippines (Wisconsin: University of Wisconsin Press, 1959) and O. D. Corpuz, The Roots of the Filipino Nation, vol. 1 (Quezon City: AKLAHI Foundation, Inc., 1989).

2 The term "bangsa" or "bansa" is a Malay word that usually refers to nations, castes, descent groups or lines, races or estates. The composite term "Bangsa Moro," refers to the "Moro Nation." MNLF and MILF prefer to use it as one word, "Bangsamoro." For the purpose of this paper, "Bangsa Moro" shall mean the "Moro Nation" and "Bangsamoro" as the "people" who embrace Islam as a religion and way of life especially those inhabiting southern Mindanao and Palawan provinces and Sulu archipelago.

3 A. Reid, "Southeast Asia in the Age of Commerce: 1450-1680," The Lands below the Winds, vol. 1 (New Haven: Yale University Press, 1993).

4 Phelan, The Hispanization of the Philippines, 4-8; Corpuz, The Roots of the Filipino Nation, 46; and R. D. McAmis, Malay Muslims: The History and Challenge of Resurgent Islam in Southeast Asia (Cambridge: William B. Eerdmans Publishing Co. 2002), 7-31.

5 Corpuz, The Roots of the Filipino Nation, 48.

6 Ibid., 111-134.

7 R. Laarhoven, Truimph of Moro Diplomacy: The Maguindanao Sultanate in the 17th Century (Quezon City: New Day Publishers, 1989), 147; J. S. Arcilla, S. J. "Jesuit Missionary Letters from Mindanao," in The Rio Grande Mission vol. 1, ed. J. S. Arcilla, S. J., (Quezon City: Archives of the Philippine Province of the Society of Jesus, 1990); R. Ileto, Magindanao: 1860-1888: 
The Career of Datu Uto of Buayan. (Ithaca: Cornell University Southeast Asia Program, 1971).

8 T. McKenna, Muslim Rulers and Rebels: Everyday Politics and Armed Separatism in the Southern Philippines (Berkeley: University of California Press, 1998).

9 N. Saleeby, The Moro Problem (Manila: Bureau of Printing, 1913), 30, cited in McKenna, Muslim Rulers and Rebels, 105.

10 S. Tan, The Filipino Muslim Armed Struggle, 1900-1972 (Manila: Filipinas Foundation, 1977), 21-22; P. Gowing, Muslim Filipinos-Heritage and Horizon (Quezon City: New Day Publishers, 1979), 77-106.

11 Philippine Commission Act No. 253, Oct. 2, 1901, cited in R. B. Thomas, "Muslim but Filipino: The Integration of Philippine Muslims, 1917-1946" (Ph.D. dissertation, Department of History, University of Pennsylvania, 1971), 9.

12 P. N. Abinales, “The 'Muslim-Filipino' and the State," Public Policy: A University of the Philippines Quarterly, vol. 2, no. 2 (April-June 1998), 3769.

13 McKenna, Muslim Rulers and Rebels, 132.

14 For a detailed account of the Moro pre-Philippine independence struggle see Gowing, Muslim Filipinos, and S. Tan, Internationalization of the Bangsamoro Struggle (Quezon City: The Centre for Integrative and Development Studies, University of the Philippines, 1993).

15 Quoted in Abinales, “The 'Muslim-Filipino' and the State," 49.

16 Muslim Association of the Philippines (MAP), Proceedings of the First National Muslim Convention, Cotabato, 8-12 June 1955 (Cotabato: Muslim Association of the Philippines, 1956), 31, emphasis added. 
17 The case was uncovered by then opposition senator Benigno Aquino Jr. Ferdinand Marcos, serving as President (1965-1986), charged that the exposé was politically motivated and meant to discredit him.

18 A tadpole-shaped island guarding the mouth of Manila Bay. It is part of Cavite Province, off south of Manila.

19 For a detailed account, see M. D. Vitug and Glenda Gloria, Under the Crescent Moon: Rebellion in Mindanao (Quezon City: Ateneo Centre for Social Policy and Public Affairs and Institute for Popular Democracy, 1999), $1-23$.

20 Violence involving Muslims and Christians escalated and plunged Mindanao into a virtual war in the decades of 1960s and 1970s. Some analysts believe that this violence between Muslims and Christians has given rise to the mistaken notion that the so-called Mindanao conflict is a religious war.

21 S. Jubair, Bangsamoro: A Nation under Endless Tyranny (Kuala Lumpur: IQ Marin, 1999), 152.

22 R. Canoy, The Counterfeit Revolution: Martial Law in the Philippines (Manila: Philippine Editions Publishing, 1980), 27.

23 Nuraladji Misuari and Salamat Hashim are the two key figures of the Muslim secessionist movement. The former led the secular Moro National Liberation Front (MNLF) in war and peace in 30 years while the latter led the Moro Islamic Liberation Front (MILF) after MNLF settled for Muslim political autonomy under the 1987 Philippine Constitution and the GRP (Government of the Republic of the Philippines)-MNLF1996 Final Peace Agreement.

24 The 13 Muslim ethnolinguistic groupings are the Maranao, Maguindanao, Tausug, Sama, Yakan, Sangil, Badjao, Kalibugan, Jama Mapun, Iranun, Palawani, Molbog, and Kalagan. Three of these are major groups occupying 
identifiable territories: Maranao in Marawi; Maguindanao in Cotabato; and Tausug-Sama in Tawi-Tawi and the Sulu group of islands.

25 E. Mercado, "Culture, Economics and Revolt in Mindanao: The Origins of the MNLF and the Politics of Moro Separatism," in Armed Separatism in Southeast Asia, ed. Lim Joo-Jock and Vani S. (Singapore: Institute of Southeast Asian Studies, 1984), 160.

26 J. Hutchinson, and A. Smith (eds.), Nationalism (Oxford: Oxford University Press, 1994), 60.

27 P. Gowing, "Moros and Khaek: The Position of Muslim Minorities in the Philippines and Thailand," in Readings on Islam in Southeast Asia, compiled by A. Ibrahim, S. Siddique, and Y. Hussain (Singapore: Institute of Southeast Asian Studies, 1985), 184-185, emphasis added.

28 The Organisation of Islamic Conference (OIC), founded in 1971, comprises 54 countries (including the non-state, Palestine). One of its major activities is to settle conflicts by peaceful means, mainly through mediation, negotiation, and arbitration. The OIC had been instrumental in forging the 1976 and 1996 GRP-MNLF Tripoli Agreement and Final Peace Agreement respectively.

29 There are conflicting versions on the founding of the MNLF. Jubair said that the MNLF was founded in 1969 while Mercado noted that its founding was in mid-1971. See Jubair, Bangsamoro, 150; and Mercado, "Culture, economics and revolt in Mindanao," 159. Interviews conducted by the author in 2000 among former MNLF leaders who were then government officials of the ARMM declare it on 28 March 1968, as MNLF's Foundation Day. Obviously, 28 March was symbolically used by the MNLF as its Founding Day since it was the day when the Jabidah massacred happened. Mercado's version is closer to reality as it was in mid-1971 when Misuari convened the "Top 90" guerrillas in Zamboanga City to repudiate the reformist tendencies of MIM and BMLO leaders. This eventually led to the birth of the MNLF. Hence, 1971 is used in this article as the year of MNLF's formation. 
30 The Tripoli Agreement was the first peace accord between the GRP and the MNLF. It directs the government to create a Muslim provisional government in the "areas of autonomy" in 13 provinces of southern Philippines where Muslims shall enjoy political autonomy.

31 "Moro National Liberation Front," in http://www.ict.org.il/inter_ter/orgdet.cfm?orgid=92 (accessed on 24 August 2004);

"The Moro Struggle for Self-Determination and the Moro Islamic Liberation Front," in http://www.db.idpproject.org/Sites/IdpProjectDb/idpSurvey.nsf/AllDocWeb/4 F62C40ACE5A0370C12568F70058401C/\$file/MILF_self-determination.PDF (accessed on 2 August 2004).

32 ARMM was created on 1 August 1989 under Republic Act 6734 as a fulfilment of Article 10, Sections 15-21 of the 1987 Constitution. It was initially composed of four provinces (Lanao del Sur; Maguindanao; Sulu; and Tawi-Tawi) and increased to six provinces when the province of Basilan and city of Marawi joined ARMM after a plebiscite was conducted on 14 August 2001.

33 The GRP-MNLF Final Peace Agreement (FPA) signed on 2 September 1996 it laid down the process and framework in achieving peace and development in Southern Philippines. See GRP-MNLF Final Peace Agreement (Manila: Malacanang Palace Press, 2 September 1996).

34 S. Tan, "The Juma'a Abu Sayyap: A Brief Assessment of its Origin, Objectives, Ideology and Method of Struggle," (Paper presented at the National Defence College of the Philippines Strategic Studies Group meeting, 2 May 2000).

35 S.A. Gutoc, "Causes of Terrorism: The Philippines Amid Southeast Asia," May 2003 (unpublished manuscript). 
36 Interview with Mohagher Iqbal, Chairman of the Committee on Information of MILF's Central Committee, conducted by the author on 24 January 2000.

37 The formation of the "Council of 15" was engineered by the MNLF's senior leaders. Misuari's Deputy Chairman, Hatamil Hassan was elected as the Council's Chair while MNLF's Foreign Affairs Committee Chair, Parouk Hussin, was elected new regional governor in November 2001.

38 A.B. Corvera, "Nur Misuari: Has the 'good warrior's' long struggle come to a disgraceful end?" 16 January 2002, in http://www.philstar.com/philstar/misua.htm (accessed on 12 October 2003).

39 A. Nawal and J. Javellana, "OIC rejects anew RP application for observer status, Gloria in KL,” Philippine Daily Inquirer (Manila), 16 October 2003.

40 The SPCPD was established through Executive Order 371 issued on 2 October 1996. It acts as a transitory administrative arm under the Office of the President tasked to promote development in 14 provinces and 9 cities (as of 1996) in Mindanao and Sulu archipelago. The covered area is known as the Special Zone of Peace and Development (SZOPAD). In the 2001 plebiscite, SZOPAD's coverage increased from 14 to 15 provinces and 9 to 14 cities as a result of the conversion of capital towns to cities and creation of new provinces by the central government between 1996 and 2001. The dissolution of the SPCPD under Executive Order 80 of 11 March 2002 transferred all its on functions, duties, and responsibilities to the new ARMM under Republic Act 9054. For details of the provisions, see EOs 371 and 80 and RA 9054 for details.

41 In November 2001, while still serving as ARMM Governor and Chair of SPCPD, Misuari convened the $5^{\text {th }}$ National Bangsamoro Assembly in Parang, Sulu and resurrected his call for an independent Muslim Mindanao. He led some armed MNLF guerrillas to attack the Army headquarters in Jolo, Sulu on 19 November 2001. This prompted the government to charge Misuari of 
sedition. He is now languishing in jail on charges of rebellion and if found guilty, he could face up to 20 years imprisonment.

42 It was also reported that Misuari pocketed funds allotted for the poverty alleviation programme and allegedly spent some P42 million (US\$840,000) to buy high-powered weapons.

43 Republic Act 9054 was passed by the Philippine Congress on 7 February 2001. It became law on 31 March 2001. RA 9054 created the new ARMM and replaced RA 6734 of 1989. As provided under the law and in compliance with the provisions of the 1996 GRP-MNLF FPA, a plebiscite was conducted on 14 August 2001 to determine possible new local governments that may want to join the new ARMM aside from the four existing ones. In the said plebiscite, Basilan and Marawi City were added. See RAs 6734 and 9054 and EO 80 for details.

44 "Sulu fighting exposes Filipino government claims to want peace in Mindanao," in http://www.muslimedia.com/phil-sulufight.htm. (accessed on 2 April 2005).

45 E. Gutierrez, "The Reimagination of the Bangsa Moro: 30 Years Hence," in Kristina Gaerlan and Mara Stankovitch (eds.), Rebels, Warlords and Ulama: A Reader on Muslim Separatism and the War in Southern Philippines (Quezon City: Institute of Popular Democracy, 2000).

46 McAmis, Malay Muslims, p.53.

47 The GFAI, signed by the GRP and MILF panels on 27 August 1998 in Sultan Kudarat, Maguindanao, enjoins both parties to reach a pacific settlement of the conflict and requires them to implement the joint agreements/arrangements previously signed, and to protect and respect human rights.

48 Also known as the "Agreement on Peace Between the Government of the Republic of the Philippines and the Moro Islamic Liberation Front," signed in 
Tripoli, Libya on 19-22 June 2001. It was the first comprehensive peace agreement signed by GRP and MILF panels after negotiations were severed in April 2000.

49 R.G. Buendia, “The GRP-MILF Peace Talks: Quo Vadis?” in D. Singh and Chin Kin Wah (eds.), Southeast Asian Affairs 2004 (Singapore: Institute of Southeast Asian Studies, 2004), pp. 205-221.

50 "MILF peace talks on track, clashes contained, says gov't," Philippine Daily Inquirer (Manila), 30 August 2004

51 "Murad extends greetings of peace and solidarity to Muslim believers", in http://www.luwaran.com 10 November 2003, (accessed on 29 August 2004).

52 "The Moro Struggle for Self-Determination and the Moro Islamic Liberation Front." in http://www.db.idpproject.org/Sites/IdpProjectDb/idpSurvey.nsf/AllDocWeb/4 F62C40ACE5A0370C12568F70058401C/\$file/MILF_selfdetermination.PDF (accessed on 2 August 2004).

53 "Murad extends greetings...."

$54 \quad$ The United Nations and Human Rights (New York: United Nations, 1978).

55 The United Nations, General Assembly Resolution 1514 (XV), Declaration on the Granting of Independence to Colonial Countries and Peoples, New York: 14 December 1960, emphasis added.

56 The United Nations, General Assembly Resolution 2625 (XXV), Declaration of Principles Concerning Friendly Relations Among States, New York: 24 October 1970.

57 R. Elusfa, "Is there hope for a GRP-MILF peace pact?" MindaNews, 12 December 2002. 
58 N. Poulantzas, Nicos. State, Power, Socialism (London: New Left Books, 1978), p. 114.

59 International Court of Justice Reports (New York: I.C.J. Report, 1975), p. 122.

60 Quoted in C.H. Williams, "Minority Nationalist Historiography," in R.J. Johnston, D.B. Knight \& E. Kofman (eds.), Nationalism, Self-Determination and Political Geography (New York: Croom Helm, 1988), p. 217.

61 K. Annan, Address to the United Nations General Assembly, New York, 20 September 1999.

62 H. Adam II, "Democracy and Self-Determination," (Speech delivered at the International Institute for Strategic Studies on 5 May 1996). The transcript of this speech was released by the Institute of Self Determination at Schloss Vadus, Liechenstein on 10 December 1997. The quotation is taken from page 12 of the transcript.

63 In 1977, Marcos created two "autonomous regions" rather than one consolidated "provisional government" as contemplated under the 1976 Tripoli Agreement. Marcos effectively divided and diluted the quest of Muslims to be governed under one Muslim-defined government.

64 "MILF peace negotiator: Autonomy option, 'tired phrase"" in http://www.luwaran.com/ 29 November 2003 (accessed on 29 August 2004).

$65 \quad$ Ibid.

66 E. Tadem, J.Reyes, and L.S. Magno, Showcases of Underdevelopment in Mindanao: Fishes, Forests, and Fruits (Davao City: Alternative Resource Center, 1984); L.S. Adriano, "Mindanao's Industry and Trade: Trends, Prospects and Agenda for Action Under the Estrada Administration," (Paper presented at the NGO-PO Summit Conference on Policy Agenda: Fulfilling the Mindanao Promise: Onward to a Sustainable and Equitable Future for its 
People, in Davao City, 24-26 June 1998; PSY [Philippine Statistical Yearbook] 1995 (Manila: National Statistics Office, 1996); and M. Macapado, The Moro Armed Struggle in the Philippines: The Non-Violent Autonomy Alternative (Marawi City: Mindanao State University, 1994).

67 Annual Per Capita Poverty Thresholds and Poverty Incidence, by Province: 1991 and 1994; 1997 and 2000 in http://www.nscb.gov.ph/poverty/2000/povertyprov.asp (accessed on 24 September 2004).

682000 Poverty Estimates - Poverty Incidence: 1997 and 2000, in http://www.nscb.gov.ph/poverty/2000/00povin1. asp (accessed on 24 September 2004).

69 F. Adriano, L. Adriano, E. Buctuanon, A. Tanada-Medina and R. Amorado, "Mindanao's Agenda for Peace and Development," Focus Asien Nr.3: Peaceful Conflict Transformation: Civil Society's Responses to the Conflict in Mindanao (Essen: Asien-Stiftung, 2001), p. 38.

70 Statistics - Education, in http://www.nscb.gov.ph/secstat/d_educ.asp (accessed on 24 September 2004).

71 Participation rate refers to the number of enrolees over the population of the age bracket eligible for the grade or year level.

72 Cohort survival refers to the number of students who survive grades 1 to 6 or first to fourth year high school.

732000 Human Development Index, in http://www.nscb.gov.ph/hdi/hdi2000.asp (accessed on 24 September 2004). 
74 S. Tan, The Socioeconomic Dimension of Moro Secessionism, (Quezon City: Centre for Integrative and Development Studies, University of the Philippines, 1995), p. 5.

75 E. Gutierrez and S. Borras Jr., The Moro Conflict: Landlessness and Misdirected State Policies, (Washington: East-West Centre, 2004).

76 F. Magdalena, Ethnicity, Identity, and Conflict: The Case of the Philippine Moros (Singapore: ISEAS Working Papers, Social and Cultural Issues 1[96], 1996), p. 26.

77 Fiesta is a socio-religious affair celebrated annually by the community, led by the Parish priest, to pay homage and thanks to the parish's patron saint. It was introduced by the Spanish catholic clergymen in the colonial period and continues to be observed in Christian communities in the Philippines.

78 Tan, The Socioeconomic Dimension of Moro Secessionism, p. 9; and Gutierrez and Borras Jr., The Moro Conflict..

79 The Philippines has 110 ethno-linguistic and cultural groups spread over 80 provinces. 